\title{
Rethinking the
}

\section{Western \\ Tradition}

The volumes in this series

seek to address the present debate

over the Western tradition

by reprinting key works of

that tradition along with essays

that evaluate each text from

different perspectives. 
EDITORIAL

COMMITTEE FOR

\section{Rethinking}

the

\section{Western}

\section{Tradition}

David Bromwich

Yale University

Gerald Graff

University of Illinois at Chicago

Gary Saul Morson

Northwestern University

Ian Shapiro

Yale University

Steven B. Smith

Yale University 


\section{Selected \\ Writings of \\ Thomas Paine}

Edited by

Ian Shapiro and

Jane E. Calvert

with an Introduction by

Ian Shapiro

with essays by

J. C. D. Clark

Jane E. Calvert

Eileen Hunt Botting

Yale

UNIVERSITY PRESS

New Haven and London 
Published with assistance from the Annie Burr Lewis Fund.

Published with assistance from the foundation established in memory of Amasa Stone Mather of the Class of 1907, Yale College.

Copyright (C) 20I4 by Ian Shapiro and Jane E. Calvert.

All rights reserved.

This book may not be reproduced, in whole or in part, including illustrations, in any form (beyond that copying permitted by Sections I07 and I08 of the U.S. Copyright Law and except by reviewers for the public press), without written permission from the publishers.

Yale University Press books may be purchased in quantity for educational, business, or promotional use. For information,

please e-mail sales.press@yale.edu (U.S. office) or sales@yaleup.co.uk (U.K. office).

Set in Times Roman and Perpetua types by Newgen North America. Printed in the United States of America.

Library of Congress Cataloging-in-Publication Data Paine, Thomas, I737-I809.

[Works. Selections. 20I4]

Selected writings of Thomas Paine / edited by Ian Shapiro and Jane E. Calvert ; with an introduction by Ian Shapiro ; with essays by J. C. D. Clark, Jane E. Calvert, Eileen Hunt Botting. pages $\mathrm{cm}$. - (Rethinking the western tradition) Includes bibliographical references and index. ISBN 978-0-300-I6745-o (pbk. : alk. paper) I. Political science-Early works to I80o. I. Shapiro, Ian, editor. II. Calvert, Jane E., I970- editor. III. Title. JCI77.A5 2014

$$
320.5 \mathrm{I}^{\prime} 2092-\mathrm{dc} 23
$$

2014005794

A catalogue record for this book is available from the British Library.

This paper meets the requirements of ANSI/NISO Z39.48-I992

(Permanence of Paper).

$$
\text { IO } 98765432 \text { I }
$$

